\title{
Available versus digestible amino acids - new stable isotope methods
}

\author{
Rajavel Elango ${ }^{1,2}$, Crystal Levesque ${ }^{3}$, Ronald O. Ball ${ }^{3,4}$ and Paul B. Pencharz ${ }^{3,4,5,6,7 *}$ \\ ${ }^{1}$ Child E Family Research Institute, BC Children's Hospital, Vancouver, British Columbia, Canada \\ ${ }^{2}$ Department of Pediatrics, University of British Columbia, British Columbia, Canada \\ ${ }^{3}$ Department of Animal and Poultry Science, University of Guelph, Ontario, Canada \\ ${ }^{4}$ Department of Agricultural, Food and Nutritional Science, University of Alberta, Edmonton, Alberta, Canada \\ ${ }^{5}$ Department of Nutritional Sciences, University of Toronto, Ontario, Canada \\ ${ }^{6}$ Research Institute, The Hospital for Sick Children, Toronto, Ontario, Canada \\ ${ }^{7}$ Department of Paediatrics, University of Toronto, Ontario, Canada
}

(Submitted 30 August 2011 - Final revision received 3 April 2012 - Accepted 24 April 2012)

\section{Abstract}

The nutritive value of food protein sources is dependent on the amino acid composition and the bioavailability of the nutritionally indispensable amino acids. Traditionally the methods developed to determine amino acid bioavailability have focused on intestinal absorption or digestibility, which is calculated as the percent of amino acid intake that does not appear in digesta or faeces. Traditional digestibility based methods do not always account for gut endogenous amino acid losses or absorbed amino acids which are unavailable due to the effect of heat processing and the presence of anti-nutritional factors, though methods have been developed to address these issues. Furthermore, digestibility based methods require the use of animal models, thus there is a need to develop in vivo methods that can be applied directly in human subjects to identify the proportion of dietary amino acids which is bioavailable, or metabolically available to the body for protein synthesis following digestion and absorption. The indicator amino acid oxidation (IAAO) method developed in our laboratory for humans has been systematically applied to determine almost all indispensable amino acid requirements in adult humans. Oxidation of the indicator amino acid is inversely proportional to whole body protein synthesis and responds rapidly to changes in the bioavailability of amino acids for metabolic processes. Using the IAAO concept, we developed a new in vivo method in growing pigs, pregnant sows and adult humans to identify the metabolic availability of amino acids in foods. The stable isotope based metabolic availability method is suitable for rapid and routine analysis in humans, and can be used to integrate amino acid requirement data with dietary amino acid availability of foods.

\section{Key words: Amino acids: Bioavailability: Metabolic availability: Indicator amino acid oxidation: Stable isotopes}

Optimal dietary protein intake will provide the $20 \alpha$-amino acids (dietary indispensable, conditionally indispensable and dispensable amino acids) in the correct proportions to meet the body's need for metabolic functions including protein synthesis $^{(1)}$. Amino acid composition of foods varies greatly. Especially of importance are the concentrations of lysine, sulphur amino acids (methionine and cysteine) and threonine ${ }^{(2)}$. In cereals, such as rice and wheat, lysine concentrations are significantly lower than in foods of animal origin. In legumes, such as chickpeas and soyabeans, methionine concentrations are significantly lower than in animal foods ${ }^{(2)}$. Thus, the study of "protein quality evaluation" of foods aims to determine the capacity of food protein sources to satisfy the metabolic demand for both amino acids and total nitrogen ${ }^{(3)}$.

The quality of dietary proteins is ultimately related to the amount of metabolically available amino acids provided at the cellular level (termed "bioavailable") for the various functions that protein and amino acids serve in maintaining normal growth and health. In other words, protein quality is a combination of the amino acid content and the bioavailability of those amino acids. The amino acid content (or composition) of common protein sources is reasonably well described ${ }^{(4,5)}$; however, there is no direct measure of amino acid bioavailability $^{(6)}$. Batterham defines bioavailability as "the proportion of the total amino acid that is digested and absorbed in

Abbreviations: BCAA, branched chain amino acids; DAAO, direct amino acid oxidation; DRI, dietary reference intakes; EAR, estimated average requirement; IAAO, indicator amino acid oxidation; IDAA, indispensable amino acids; MA, metabolic availability; NPU, net protein utilization; NPPU, net postprandial protein utilization; PDCAAS, protein digestibility-corrected amino acid score; PER, protein efficiency ratio; RDA, recommended dietary allowance; SAA, sulphur amino acids; TD, true digestibility.

*Corresponding author: P. B. Pencharz, fax +416-813-4972, email paul.pencharz@sickkids.ca 
a form suitable for protein synthesis"(7). Thus, the bioavailability of amino acids is dependent not only on the digestibility of the dietary proteins, but also on the subsequent absorption, and potential utilization of the absorbed amino acid for metabolic processes.

Within the context of protein quality evaluation for human nutrition, numerous methods have been developed to assess protein quality; however, based on the definitions above most of the methods provide an estimate of bioavailability rather than "protein quality" per se. Tomé and colleagues ${ }^{(8-10)}$ suggest that protein quality evaluation methods that encompass both digestibility and protein retention, and thus account for short-term protein utilization, are of primary interest. They also conclude, "that protein quality, in terms of protein utilization, is more than a simple function of the indispensable amino acid content". The focus of this review is on methods used to define the nutritional value of proteins in relation to the proportion of bioavailable amino acids and protein from protein sources as it relates to practical application in humans. In this context, experimental methods that determine digestibility and/or protein utilization are considered to provide an estimate of bioavailability.

Traditionally, bioassays using growing rats were the preferred approach to assess the nutritional value of proteins for humans, and were expressed as protein efficiency ratio (PER), net protein utilization (NPU), biological value and more recently as the protein digestibility-corrected amino acid score (PDCAAS). The PER, NPU, and biological values measure whole body protein utilization and thus provide an estimate of bioavailability, whereas, PDCAAS is a measure of protein quality as defined above. Several shortcomings of these methods have been identified ${ }^{(11,12)}$; therefore, there is a need to develop more sensitive and appropriate techniques directly in humans to estimate amino acid bioavailability. Using the minimally invasive indicator amino acid oxidation (IAAO) technique developed to determine amino acid requirements in humans, we have recently developed a new method to estimate the whole body bioavailability, termed "metabolic availability", of IDAA from dietary protein sources ${ }^{(13,14)}$. The current review will outline the concerns related to existing traditional methods and describe the development of the new stable isotope based metabolic availability method in pigs and humans.

\section{Earlier Methods and Related Concerns \\ Protein Efficiency Ratio}

One of the earliest approaches to assess the nutritional quality of proteins for humans was the use of bioassays using growing rats. The Protein Efficiency Ratio (PER) method, which determines the ability of a protein to support growth in young rapidly growing rats, has been applied since 1919 for the routine assessment of protein quality of foods ${ }^{(2)}$. The PER is calculated as the body weight gain in $\mathrm{g}$ per $\mathrm{g}$ of test protein consumed. However, the PER overestimates the value of animal proteins and underestimates the value of vegetable proteins. This is primarily because the rapid growth rate of rats increases the proportion of the protein that needs to be IDAA, in comparison to the slow growth rates in humans ${ }^{(15)}$. Additionally, PER is a measure of total protein and not individual amino acid utilization.

\section{Protein Digestibility-Corrected Amino Acid Score (PDCAAS)}

Due to the disadvantages of the PER method, an alternative method, the amino acid score method, was proposed for the routine assessment of protein foods during a joint Food and Agriculture Organization/World Health Organization (FAO/WHO) Expert Consultation on Protein Quality Evaluation in $1989^{(15)}$. The amino acid score is defined as the concentration of the limiting amino acid in the food protein and is expressed as a percentage of the concentration of the same limiting amino acid in a reference amino acid pattern, which is the essential amino acid requirements of preschoolage children, as recommended by the $1985 \mathrm{FAO}^{(2)}$. The amino acid score for each protein derived by the above described procedure is subsequently corrected for the true faecal protein digestibility (TD) of the test protein, as determined by using a rat model. TD is defined as the difference between the dietary intake of protein $\mathrm{N}$ and faecal $\mathrm{N}$ excretion, expressed as a \% of the dietary $\mathrm{N}$ intake. Endogenous faecal $\mathrm{N}$ is taken into account by feeding rats a protein free diet $^{(16)}$. This modified amino acid score method is referred to as the Protein Digestibility-Corrected Amino Acid Score (PDCAAS). The PDCAAS is unique compared to other methods of protein quality evaluation because it is primarily a function of the gross amino acid content of a protein source. However, it is currently recommended as the method of choice for the routine assessment of protein quality of foods for humans ${ }^{(15,16)}$ and therefore has been included in the current discussion.

Since its introduction in 1991, the PDCAAS has been extensively studied and various limitations have been reported $^{(16,17)}$. Specific concerns regarding the PDCAAS method include:

(1) The use of Estimated Average Requirement (EAR) estimates as the reference rather than the safe or RDA estimates. As well, the current reference pattern is restricted to the IDAA and does not take into account the conditionally IDAA ${ }^{(16)}$;

(2) The PDCAAS method does not adequately recognize the nutritional value of high quality proteins because values higher than $100 \%$ are truncated to $100 \%$. Therefore, differences between two proteins such as milk and soya proteins are not distinguished, although the actual concentrations of some IDAA and the capacity to complement other food sources are higher in milk than in soya $\operatorname{protein}^{(15)}$

(3) The PDCAAS method utilizes digestibility values derived from faecal digestibility coefficients in a rat model. This has many problems at several levels, including the use of rat digestibility values and the use of faecal versus ileal digestibility values. 
(4) The PDCAAS method does not take into account the large variations that exist between digestibility values for entire proteins and individual amino acids ${ }^{(18)}$. For example, in human milk, indispensable amino acid digestibility ranged from $86 \%$ for threonine to $100 \%$ for methionine and tyrosine ${ }^{(18)}$.

(5) Another key concern with the PDCAAS method is with respect to application of the method to foods that have been heat processed. Protein foods subjected to heat/alkaline processing to improve food flavour and texture, or sterilization / pasteurization may cause the formation of compounds that render the amino acids unavailable for protein synthesis; for example: Maillard compounds, oxidized forms of sulphur amino acids, D-amino acids, and cross-linked peptide chains, such as lysinolalanine ${ }^{(19)}$.

(6) Furthermore, some foods naturally contain antinutritional factors, such as trypsin inhibitors in soya protein, tannins in legumes and cereals, and phytates in cereals. These decrease the bioavailability of amino acids from the food sources ${ }^{(20)}$; the PDCAAS method does not take into account these factors and thus tends to overestimate the protein quality of such products ${ }^{(19,21)}$.

\section{Protein and amino acid digestibility}

Digestibility is the percentage of protein or amino acid intake that has disappeared from the digestive tract and has become the standard measure to estimate bioavailability. Digestibility can be divided into faecal (or total tract) and ileal digestibility. Ileal digestibility can be further separated into apparent, standardized, or true depending on the method of correction for endogenous losses ${ }^{(6)}$. Nearly all of the absorption of amino acids occurs in the small intestine, prior to the end of the ileum, which means that faecal digestibility is a poor estimate of actual amino acid bioavailability. There is extensive evidence demonstrating microbial degradation of protein and amino acids in the hindgut ${ }^{(11,22)}$. Therefore, faecal digestibility values tend to overestimate the bioavailability of many amino acids in dietary protein ${ }^{(11)}$. Conversely, microbes in the hindgut also synthesize many amino acids, which can lead to underestimation of the ileal availability.

Extensive research in pigs ${ }^{(4)}$ clearly demonstrates that ileal digestibility coefficients, which are determined by measurements made of the quantity of amino acids remaining at the end of the small intestine, or ileum, provide a more accurate estimate of protein and amino acid bioavailability. Despite being a major improvement compared to faecal digestibility, ileal digestibility of amino acids is not equal to the true amino acid bioavailability. The reader is directed to detailed reviews of the advantages and potential limitations of ileal digestibility methods $^{(6,17)}$ and these will not be discussed in detail here. Briefly, three limitations with traditionally determined ileal digestibility are: (1) not all absorbed amino acids are in a form that is biologically available; (2) the quantity of amino acids excreted into the gut, called endogenous protein loss ${ }^{(4)}$, with different foods ${ }^{(20)}$ and must be accurately accounted for; (3) the method requires sampling of ileal digesta. Surgical implantation of a simple t-cannula is a popular technique for collection of ileal digesta in animals ${ }^{(23)}$ but is not applicable to humans. Healthy adult ileostomates ${ }^{(12)}$ and intestinal intubation ${ }^{(8)}$ have been used to determine ileal amino acid digestibility values for humans, but the methods are not suited for routine application thus animal models such as the growing pig or rat are used.

As described earlier, heat processing may cause the formation of compounds that render the amino acids unavailable for protein synthesis. Although unavailable for protein synthesis, these altered amino acids are partly digested and absorbed. Because of the presence of chemically altered AA in heat damaged protein, and their interference during amino acid analysis, traditional estimates of amino acid digestibility can be in error for processed foods. Methods have been developed to address these problems. The reactive lysine assay may be used to assess the degree of chemical modification of lysine in foods due to heat but does not account for incomplete digestion or absorption from the gut $^{(24)}$. Digestible reactive lysine ${ }^{(24,25)}$ incorporates true ileal digestibility as well as reactive lysine measurement in both the food and ileal digesta and thus provides a more accurate estimate of the effect of heat damage to lysine bioavailability than the reactive lysine content of the foodstuff alone. The digestible reactive lysine assay has been shown to provide reliable estimates of lysine bioavailability in damaged proteins $^{(25)}$.

\section{Stable isotope based methods for in vivo estimation of amino acid bioavailability of foods}

Batterham $^{(7)}$ suggests that based on the definition of amino acid bioavailability stated previously, techniques that measure the utilization of an amino acid are important for estimating bioavailability. There is a need to develop methods that account for digestibility as well as metabolic utilization of amino acids. Dietary protein utilization is influenced by multiple factors including individual amino acid requirements, dietary energy and nitrogen intakes, genetic and environmental influences, age, physiological stage, presence of antinutritional factors, processing treatments and interactions among other components of the diet ${ }^{(12)}$. Therefore, the development of new techniques to estimate bioavailability must take care to control or account for the influence of these factors.

We $\mathrm{W}^{(13,14,26,27)}$ have recently applied the IAAO method using carbon $\left({ }^{14} \mathrm{C}\right.$ or ${ }^{13} \mathrm{C}$ - labeled amino acid) oxidation as an indicator of amino acid bioavailability, while others ${ }^{(7-9,28)}$ have applied the use of $\left[{ }^{15} \mathrm{~N}\right]$-labeled proteins to determine net postprandial protein utilization (NPPU), or $\left[{ }^{13} \mathrm{C}\right]$-leucine balance to predict $\operatorname{PPU}^{(29,30)}$.

\section{Net postprandial protein utilization (NPPU)}

$\left[{ }^{15} \mathrm{~N}\right]$-labeled proteins (milk, soya protein isolate and wheat) have been used to measure the metabolic fate of dietary nitrogen after its consumption in humans. NPPU is calculated using true ileal digestibility and ${ }^{15} \mathrm{~N}$-labeled protein deamination 
parameters ${ }^{(9)}$. Intrinsic labelling of dietary proteins with ${ }^{15} \mathrm{~N}$ allows the investigation of postprandial $\mathrm{N}$ transfers into different metabolic pools. Ileal digesta, blood and urine are sampled. The kinetics of dietary $\mathrm{N}$ appearance in ileal effluents, plasma proteins, plasma free AA, body urea, urinary urea and urinary ammonia are calculated using a 13-compartment, 21 parameter model $^{(31)}$. NPPU values determined for milk, soya protein isolate and wheat are $81 \%, 78 \%$ and $66 \%$, respectively ${ }^{(7-9,32)}$.

This method is a major advancement in the evaluation of protein quality because it determines protein digestibility and post-prandial protein utilization; however, it is restricted to foods which can be intrinsically labeled with ${ }^{15} \mathrm{~N}$ and during the study, ileal digesta are collected using a nasointestinal intubation technique. Therefore, this method is unlikely to be widely adopted for routine application. The model calculations are fairly complex ${ }^{(31)}$. Furthermore the NPPU technique cannot be used to determine the utilization of individual amino acids.

\section{Postprandial protein utilization (PPU)}

Millward et al. ${ }^{(29)}$ used a $\left[1-{ }^{13} \mathrm{C}\right]$-leucine balance protocol and a single meal of wheat or milk protein to predict postprandial protein utilization (PPU). From the measurement of ${ }^{13} \mathrm{C}$ leucine oxidation, leucine and nitrogen balances were predicted using the cumulative difference between the pre-meal and post-meal leucine oxidation rate, which is converted to a nitrogen retention value based on an assumed body tissue protein leucine:nitrogen ratio, and the meal nitrogen intake. Nitrogen utilization is assumed to be equivalent to "leucine intake less the meal-dependent leucine oxidation", and utilization of wheat protein is assumed to be limited by the lysine content ${ }^{(29)}$. Using this method the authors predicted wheat PPU to be 0.61 using the single meal pattern ${ }^{(29)}$ or 0.68 using frequent small meals ${ }^{(30)}$. The method as described above involves several assumptions which have not been validated in subsequent studies, and has been severely criticized by others ${ }^{(33)}$. It is not possible to accurately determine the PPU for nitrogen present in the test meal by the present method because it is impossible to estimate how much of leucine oxidized in the $6 \mathrm{~h}$ postprandial period is due specifically to exogenous (dietary) and endogenous sources of leucine. The route of isotope delivery was intravenous, and it is unclear whether bypassing the small intestine for the route of isotope had any impact on the measurement of PPU. It is also not clear whether the methodological concerns can be solved with respect to the PPU method, and will be suitable for routine application.

\section{Application of the IAAO method to determine the metabolic availability (MA) of amino acids}

The IAAO technique is based on the concept that when one IDAA is deficient for protein synthesis, then the relative surplus of other amino acids including the indicator amino acid (another IDAA, usually L-[1- $\left.{ }^{13} \mathrm{C}\right]$ phenylalanine) will be oxidized $^{(34)}$. Fundamentally, this is because amino acids cannot be stored and therefore must be partitioned between incorporation into protein or oxidation. With increasing intake of the limiting amino acid, oxidation of the indicator amino acid will decrease, reflecting increasing incorporation into protein. Once the requirement for the limiting amino acid is met, there will be no further change in the oxidation of the indicator amino acid. The inflection point where the oxidation of the indicator amino acid stops decreasing and reaches a plateau is referred to as the 'breakpoint'. The breakpoint identified with the use of bi-phase linear regression analysis indicates the mean or EAR of the limiting (test) amino $\operatorname{acid}^{(34)}$. This minimally invasive IAAO method has been systematically applied to determine IDAA requirements in adult humans ${ }^{(34-36)}$.

The IAAO method can be applied to estimate the bioavailability of AA, termed metabolic availability (MA) ${ }^{(13,26,37)}$. The IAAO is inversely proportional to the rate of protein synthesis ${ }^{(38,39)}$. Therefore, at a given amino acid intake, the relative difference in the IAAO rate between test and reference proteins will be proportional to the whole body MA of the test amino acid for protein metabolism, and thus account for all losses of dietary amino acids during digestion, absorption, and cellular metabolism (Fig. 1). The total losses taken into account by the IAAO method include: incomplete digestion and absorption, gut endogenous amino acid losses, and the unavailability of absorbed amino acids from foods due to the presence of anti-nutritional factors (i.e. Maillard compounds formed due to processing of foods, D-amino acids, and cross linked proteins such as lysinoalanine). In simple terms, the higher the oxidation of the indicator amino acid, the lower the MA of the test amino acid for protein metabolism and vice-versa (Fig. 1).

Metabolic availability is based on the principle of the slope-ratio assay where changes in a measured response (i.e. growth) due to changes in intake of the test protein source are compared to the change in response to a reference protein. Assays of amino acid bioavailability that measure parameters of growth (i.e. slope ratio assays) are considered the standard against which other methods of amino acid bioavailability are judged ${ }^{(1)}$. The advantages of slope ratio assays that measure parameters of protein synthesis are that they account for the effect of digestion, absorption and metabolic utilization of the AA provided by the protein source and measure a response that has practical and economic consequences ${ }^{(1)}$ which is of particular importance in animal nutrition. However, one limitation of the slope-ratio assay is that only one amino acid can be examined at a time. Traditionally, body weight or feed efficiency were used to evaluate 'growth' in relation to slope-ratio assays ${ }^{(10)}$ but may require extended periods of time to measure a change of statistical significance. The short adaptation time ( $<2$ days) of the IAAO technique ${ }^{(40)}$ means that multiple amino acids from a protein source may be evaluated in a relatively short period overcoming the limitation of measuring single amino acids at a time. The slope ratio assay is dependent on a number of key criteria ${ }^{(7)}$ which are discussed further below. 


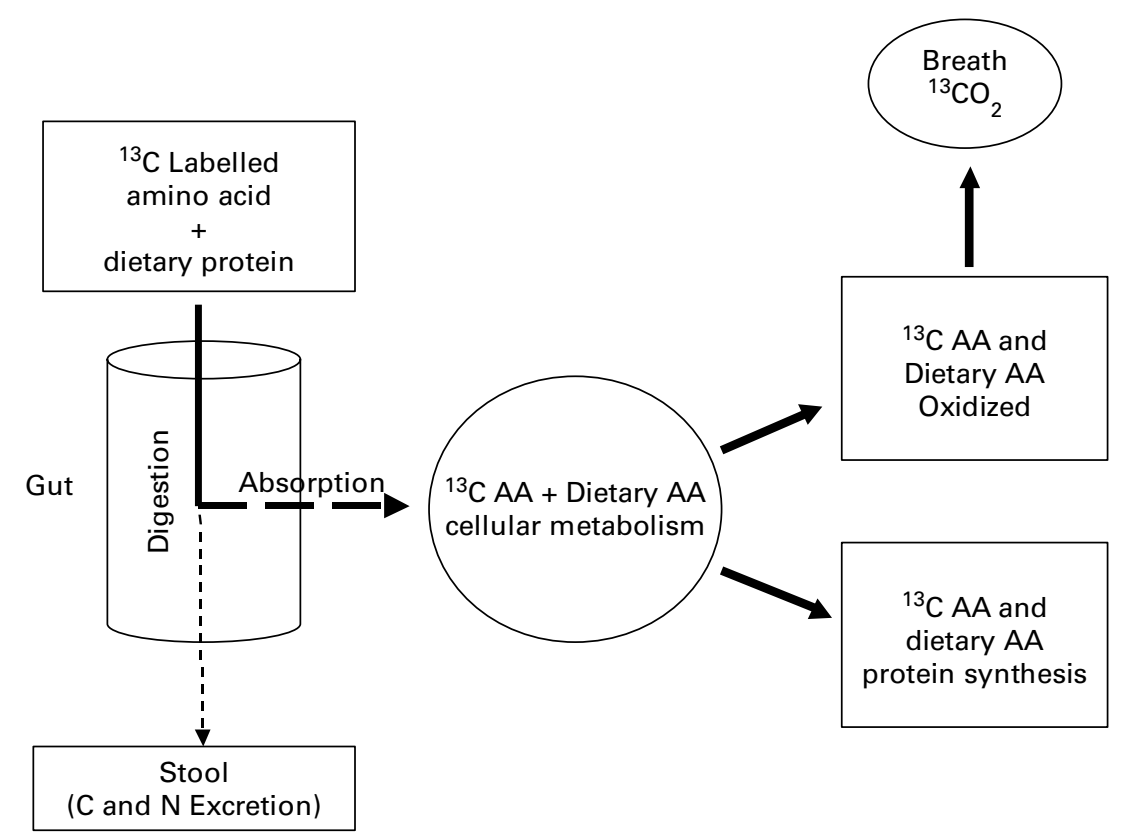

Fig. 1. Conceptual application of indicator amino acid oxidation (IAAO) to determine metabolic availability of amino acids from food sources IAAO is inversely proportional to the rate of protein synthesis. Total losses taken into account by the IAAO method include: incomplete digestion and absorption, gut endogenous amino acid losses, and the unavailability of absorbed amino acids from foods due to the presence of anti-nutritional factors, Maillard compounds formed due to processing of foods, D-amino acids, and cross linked proteins. Thus, the higher the oxidation of the indicator amino acid (breath ${ }^{13} \mathrm{CO}_{2}$ ), the lower the metabolic availability of the test amino acid for protein synthesis and vice-versa.

\section{Metabolic availability of lysine in pigs}

The initial development of the IAAO method to measure MA was conducted in growing pigs. We ${ }^{(41,42)}$ and others ${ }^{(43,44)}$ have successfully used the pig as a model for human protein and amino acid nutrition studies. Anatomical and digestive physiology similarities exist between the pig and human especially with respect to protein and amino acid metabolism, and pigs are well suited for in vivo amino acid bioavailability studies.

The MA of lysine from peas in growing pigs $(15-18 \mathrm{~kg})$ was determined by comparing the oxidation of the indicator amino acid (intravenously delivered $1-{ }^{14} \mathrm{C}$-phenylalanine) to that of pigs fed free lysine (crystalline form) ${ }^{(13)}$. It has been shown previously that the true digestibility of crystalline amino acids in pigs is essentially $100 \%{ }^{(45,46)}$. To determine metabolic availability using this method, key criteria must be fulfilled ${ }^{(47)}$ : 1) the test amino acid must be first-limiting to ensure that it is the dietary intake of this amino acid that drives the change in indicator oxidation rates; 2 ) the response of the oxidation rate to increments of the test amino acid must be predictable to allow calculation of availability. For this criterion to be met, the intake of the limiting amino acid must be below the lower confidence interval (CI) of the requirement level in every individual (Fig. 2, Panel A). As well, care must be taken during experimental diet formulation to ensure that other dietary nutrients are similar between test and reference diets so that the only factor driving IAAO is the level of the test $\mathrm{AA}$ intake ${ }^{(47)}$.

The test diets, raw peas and heated peas (to render some of the lysine unavailable by Mallard reaction), were fed at the
$80 \%$ of lysine requirement level and IAAO measured ${ }^{(13)}$. Replacing the free lysine with equal amounts of protein bound lysine from both samples of raw peas increased IAAO oxidation, demonstrating a lower availability of lysine (Table 1). Heated peas increased IAAO more than raw peas, demonstrating that lysine bioavailability was decreased due to the heating process. MA was calculated from the ratio of the response to the addition of lysine intake from peas/ heated peas to that of free lysine (Table 1). The MA of lysine from raw peas was determined to be $88 \%$, compared to $55 \%$ from heated peas. These values were comparable to earlier published estimates determined using slope-ratio growth assays $^{(48)}$ and digestible reactive lysine ${ }^{(25)}$ where the bioavailability of raw peas was 85 and $87.9 \%$, respectively and the bioavailability of similarly heated peas was 48 and $67 \%$, respectively. It should be noted that in similarly heated peas, the reduction in lysine bioavailability was $>30 \%$ when based on MA or the slope ratio assay but $20 \%$ when based on digestible reactive lysine.

The method was adapted for oral isotope delivery ${ }^{(26)}$ to make the method minimally invasive and more applicable for routine use. The MA of lysine from soyabean meal (87.5\%, Table 1) correlated well with reported values of $88 \%$ for soyabean meal based on standardized ileal digestibil${ }^{i t y}{ }^{(26)}$. The MA of raw and heated peas was $76 \%$, and $68.3 \%$, respectively. Different feedstuffs and less severe heating conditions were applied in the latter study, which rendered less lysine unavailable. When heated peas were supplemented with free lysine, to the amount that was calculated to be lost during heating, the MA of lysine was determined to be 
A

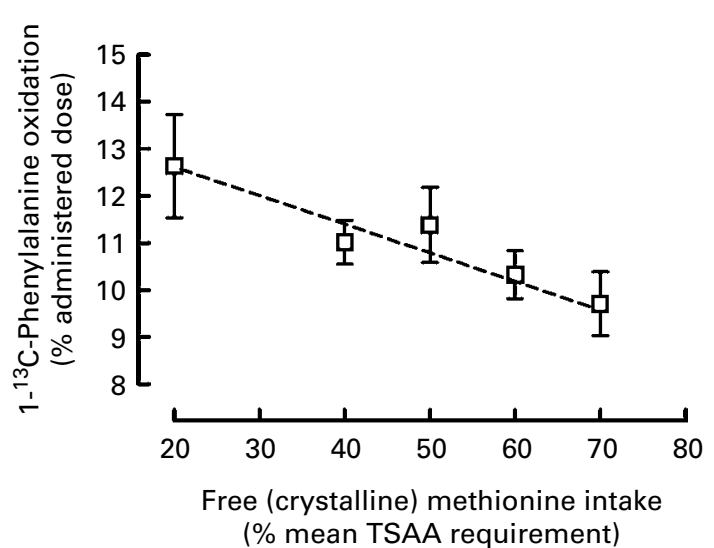

$\mathrm{B}$

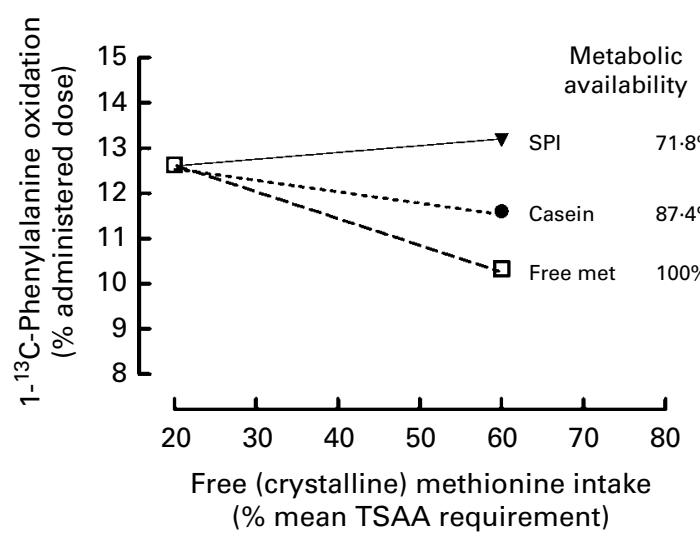

Fig. 2. Pattern of response observed in indicator amino acid oxidation due to intake of free (crystalline) methionine and intact proteins Panel A: Oxidation response measured in breath of orally administered $\mathrm{L}-1-{ }^{13} \mathrm{C}$-Phenylalanine (\% administered dose) following graded intake of free (crystalline) methionine. Values are means \pm SEM; $n=7$ human subjects; TSAA, total sulphur amino acids Panel B: Oxidation response of orally administered $\mathrm{L}-1-{ }^{13} \mathrm{C}$ Phenylalanine ( $\%$ administered dose) following intake of free (crystalline) methionine, versus casein and soya protein isolate (SPI) at $60 \%$ of mean methionine requirement ( $\mathrm{n}=7$ subjects) At a given amino acid intake, relative difference in the IAAO rate between test and reference proteins (free crystalline form) will be proportional to the whole body metabolic availability (MA) of the test amino acid for protein synthesis, and thus account for all losses of dietary amino acids during digestion, absorption, and cellular metabolism. The MA is calculated from the ratio of the response to the addition of amino acid intake from test proteins to that of free (crystalline) amino acids. To ensure that the test amino acid is first limiting, the intake of the test amino acid must be below the lower confidence interval $(\mathrm{Cl})$, i.e. 1 or $2 \mathrm{SD}$ below the EAR in every individual, as established in Panel A. Adapted from Humayun et al. ${ }^{(14)}$

$76.5 \%$, similar to the raw peas (Table 1 ). Therefore, the MA method is sensitive to changes in lysine bioavailability.

\section{Metabolic availability of threonine in pigs}

By applying the method described by Moehn et al. ${ }^{(13)}$ in pregnant sows, the MA of threonine in corn was determined to be $88.0 \%$ and in barley $89.3 \%{ }^{(27)}$. These results were 7 and $9 \%$ greater than the published standard ileal digestibility of threonine in corn (82\%) and barley (81\%), respectively, based on growing pig data(4). Previous studies have also suggested that pregnant sows have a greater capacity to digest and utilize protein-bound amino acids compared to growing pigs ${ }^{(49,50)}$ The standard ileal digestibility of crude protein and amino acids of individual feed grains averaged $10 \%$ greater in pregnant sows with a range from 1.7 to $16 \%{ }^{(49)}$. The threonine MA study ${ }^{(27)}$ results also suggest approximately $10 \%$ greater availability of amino acids in feedstuffs fed to adult sows compared to growing pigs.

Higher nutrient availability in sows is partly due to feed restriction, which increases digestibility in pigs by $10-15 \%{ }^{(4)}$. To support the increased demand for nutrients and changes in nutrient metabolism that occur during pregnancy, utilization of nutrients from the diet may be altered by increasing intestinal absorption ${ }^{(51)}$. Apparent ileal AA digestibility was $10 \%$ higher in mated ewes compared to non-mated ewes ${ }^{(52)}$. An increase in the specific activity of digestive enzymes has been shown to occur during late pregnancy and lactation in rats ${ }^{(53)}$. Therefore, the increased availability of threonine from corn and barley in sows may be due to the physiological state of pregnancy which leads to more efficient absorption of amino acids from dietary sources. These results also highlight the ability of the metabolic availability method to be applied during different physiological conditions. The method also yields meaningful results, which can be applied to improve health by tailoring nutrient supply to specific physiological needs.

\section{Metabolic availability of sulphur amino acids in humans}

We ${ }^{(13)}$ recently adapted the method in humans to determine the MA of SAA from casein versus soya protein isolate (SPI) using $\mathrm{L}-\left[1-{ }^{13} \mathrm{C}\right]$ phenylalanine as the indicator amino acid Healthy young men received free methionine (crystalline form) at 20, 40, 50 and $70 \%$ of the TSAA requirement $(13 \mathrm{mg} / \mathrm{kg} / \mathrm{d})$ previously determined in our laboratory ${ }^{(54)}$. With increasing intake of free methionine, a linear decrease in indicator oxidation rate was observed (Fig. 2, Panel A). SPI was also tested to be first limiting in methionine for protein synthesis in these subjects, by the addition of free methionine to a test diet containing $40 \%$ of the TSAA requirement. It was observed that indicator oxidation decreased significantly due to the addition of free methionine to the SPI test diet when compared to the unsupplemented group $^{(13)}$. The test proteins, casein and SPI were provided at $60 \%$ of the TSAA requirement in the same subjects and the IAAO response compared against the IAAO response observed with addition of free methionine (Table 2 and Fig. 2, Panel B). All other amino acids, except the SAA, were present in excess and were identical in content among the reference and test proteins. Therefore, changes in the IAAO between diets with free methionine versus SAA from casein or SPI reflected the metabolic availability of the SAA. The MA was calculated from the ratio of the response to the addition of amino acid intake from test proteins to that of free (crystalline) amino acids. The MA of SAA in casein and the SPI were determined to be 87 and $72 \%$, respectively, which are comparable to earlier published net protein utilization (NPU) values of $80-85 \%$ for milk proteins and $71-78 \%$ for soya proteins (Table 2). 
Table 1. Metabolic availability of lysine in foods fed to swine

\begin{tabular}{|c|c|c|c|c|}
\hline \multirow[b]{2}{*}{ Amino Acid Intake } & \multirow{2}{*}{$\begin{array}{l}\text { IAAO Response } \\
\text { (\% of dose } / g \text { lysine } \\
\text { intake) } \\
\text { Mean }\end{array}$} & \multicolumn{2}{|c|}{$\begin{array}{l}\text { Metabolic } \\
\text { Availability }\end{array}$} & \multirow{2}{*}{$\begin{array}{l}\text { Ileal Digestibility } \\
(\%)\end{array}$} \\
\hline & & SEM & $(\%)$ & \\
\hline \multicolumn{5}{|l|}{ Moehn et al. ${ }^{(13) *}$} \\
\hline Free Lysine (crystalline form) & $-3 \cdot 16$ & 0.39 & 100 & \\
\hline Raw Peas & $-2 \cdot 81$ & 0.44 & $88 \cdot 8$ & $85^{(48)}$ \\
\hline $\begin{array}{l}\text { Heated Peas } \\
\text { Moehn }{ }^{(26)}{ }_{t}\end{array}$ & $-1 \cdot 73$ & 0.41 & $54 \cdot 8$ & $48^{(48)}$ \\
\hline Free Lysine (crystalline form) & -3.63 & 0.43 & 100 & \\
\hline Soyabean meal & $-3 \cdot 18$ & 0.32 & 87.5 & $88^{(55)}$ \\
\hline Canola meal & -2.59 & 0.31 & 71.4 & $74-79^{(55)}$ \\
\hline Cottonseed meal & $-2 \cdot 73$ & 0.38 & $75 \cdot 1$ & $45-70^{(56)}$ \\
\hline Raw Peas & $-2 \cdot 75$ & 0.29 & 75.8 & $85^{(48)}$ \\
\hline Heated Peas & -2.48 & 0.30 & 68.3 & $48^{(48)}$ \\
\hline Heated Peas plus free Lysine & $-2 \cdot 78$ & 0.27 & $76 \cdot 5$ & \\
\hline \multicolumn{5}{|l|}{ Levesque et al. ${ }^{(27)} \ddagger$} \\
\hline Free Threonine & & & & \\
\hline (crystalline form) & -1.59 & 0.53 & 100 & \\
\hline Corn & -1.40 & 0.62 & 88.0 & $82^{(4)}$ \\
\hline Barley & -1.42 & 0.81 & 89.2 & $81^{(4)}$ \\
\hline
\end{tabular}

* Moehn et al. ${ }^{(13)}, \mathrm{n}=4$ growing pigs.

† Moehn et al. ${ }^{(26)}, \mathrm{n}=8$ growing pigs.

$\ddagger$ Levesque et al. ${ }^{(27)} \mathrm{n}=6$ pregnant sows.

In the human study we also studied IAAO responses with the provision of graded increases in TSAA (40, 50, 60 and $70 \%$ ) from casein and SPI, while supplementing all other amino acids to ensure only the SAA from test proteins were limiting. We did not observe a linear decrease in IAAO with increasing SAA from test proteins, as we had observed for the graded increases in free methionine ${ }^{(13)}$. We reasoned that this was possibly due to the provision of a mixture of free and protein-bound amino acids in the minimally adapted IAAO protocol. In our previous work ${ }^{(40)}$ using IAAO to estimate amino acid requirements in humans an adaptation period of $<8 \mathrm{hr}$ was adequate for adaptation to changes in test amino acid intakes when crystalline amino acids were used. This same adaptation period $(<8 \mathrm{hr})$ was used for the test protein (i.e. protein-bound amino acids); however, this may not be sufficient adaptation time for intact proteins. Thus an inadequate adaptation period may have affected the tracer/tracee ratio for the indicator amino acid. To ensure that reliable estimates for TSAA availability can be obtained, we repeated the study in the same human subjects at the $60 \%$ TSAA intake level. Similar metabolic availability for both casein (90.5 vs. 90.6\%) and soya protein (70.6 vs. $69.9 \%$ ) were obtained in the second experiment, compared to the first experiment ${ }^{(13)}$. The $60 \%$ TSAA intake level was chosen to determine availability because it is one SD below the EAR for methionine in each individual ${ }^{(54)}$, and meets the criterion that the intake of the limiting amino acid must be below the lower confidence interval (CI) of the requirement level in every individual for the change in IAAO to be predictable (Fig. 2). Future studies in humans need to be conducted to further validate this new concept to determine "metabolic availability". This method to determine amino acid availability may be more practical and suitable for humans compared to other current in vivo methods for the routine application in various food sources.

\section{Summary}

Amino acid requirements in human adults, neonates, children, and in diseased individuals have been systematically studied using the IAAO method ${ }^{(34-36)}$. The IAAO concept has now been applied to determine the in vivo bioavailability, termed "metabolic availability", of amino acids from foods for protein synthesis in pigs and humans. The results from studies in pigs suggest that MA can be determined for individual amino acids including lysine, threonine and methionine, typically the first limiting amino acids in diets containing proteins from vegetable origin. The MA also can be applied to determine amino acid losses (especially lysine) due to heat processing of foods. Digestible reactive lysine also accounts for losses in lysine bioavailability due to heat processing but requires sampling of ileal digesta to determine true ileal amino acid digestibility. The adaptation of the study in humans to determine methionine availability has opened the way for further validation and work directly in humans to determine amino acid availability. The other stable isotope based method in humans (using ${ }^{15} \mathrm{~N}$-labeled proteins ${ }^{9}$ ) requires sampling of ileal digesta, intrinsic labelling of food proteins and thus is limited in its application. Compared to the ${ }^{15} \mathrm{~N}$-labeled protein

Table 2. Metabolic availability of total sulphur amino acids in casein and soya protein fed to humans*

\begin{tabular}{|c|c|c|c|}
\hline \multirow[b]{2}{*}{ Amino Acid Intake } & \multicolumn{2}{|c|}{$\begin{array}{c}\text { Breath }{ }^{13} \mathrm{CO}_{2} \\
\text { (\% of dose) }\end{array}$} & \multirow{2}{*}{$\begin{array}{c}\text { Metabolic } \\
\text { Availability } \\
(\%)\end{array}$} \\
\hline & Mean & SEM & \\
\hline Free methionine (crystalline form) & $10 \cdot 3$ & 0.5 & 100 \\
\hline Casein & $11 \cdot 6$ & 0.6 & $87 \cdot 4$ \\
\hline Soya protein isolate (SPI) & $13 \cdot 2$ & 0.5 & $71 \cdot 8$ \\
\hline
\end{tabular}

${ }^{*}$ Humayun et al. ${ }^{(14)}, \mathrm{n}=7$ healthy young men. 
method the IAAO method is easier to conduct, less expensive, less invasive, and provides estimates of individual amino acid bioavailability. Future studies need to be conducted to further validate the method for routine application in humans.

Practical application of protein quality evaluation of protein sources includes consideration of the amino acid profile as well as the bioavailability of the amino acids. There are numerous methods to estimate bioavailability; however, amino acid digestibility is currently the most widely used. Standard ileal digestibility provides a reasonable estimate of bioavailability for many foods but it does not account for incomplete digestion and absorption of structurally altered amino acids or short-term amino acid utilization for protein metabolism. The digestible reactive lysine method has been shown to more accurately estimate lysine bioavailability in heat-damaged proteins. The MA method is superior to digestibility as an estimate of bioavailability because it provides estimates of amino acid availability subsequent to digestion and absorption of the test proteins. A new indicator of protein quality for practical application to human nutrition based on amino acid profile and MA would be superior to the current PDCAAS because it would account for differences in protein and AA bioavailability, account for amino acid losses due to heat damage, and be measured directly in humans rather than animal models.

\section{Acknowledgements}

The authors have no conflicts of interest. All authors contributed in the preparation of the manuscript.

Supported by the Canadian Institutes for Health Research (grant \# MOP 10321).

\section{References}

1. Lewis AJ \& Bayley HS (1995) Amino acid availability. In Bioavailability of nutrients for animals - amino acids, minerals, and vitamins, pp. 35-65 [CB Ammerman, DH Baker and AJ Lewis, editors]. San Diego, CA: Academic Press.

2. Young VR \& Pellett PL (1994) Plant proteins in relation to human protein and amino acid nutrition. Am J Clin Nutr 59, 1203S-1212S.

3. Food and Agricultural Organization (2007) Protein and amino acid requirements in buman nutrition. Report of a joint WHO/FAO/UNU expert consultation. WHO Technical Report Series, No. 935. Geneva, Switzerland.

4. NRC (1998) National Research Council, Nutrient Requirements for Swine, 10th Ed. Washington, DC: National Academy Press.

5. ISDA/ARS (2006) Composition of foods: raw, processed, prepared, USDA National Nutrient Database for Standard Reference, Release 19, August 2006. US Department of Agriculture, Agricultural Research Service.

6. Stein HH, Sève B, Fuller MF, et al. (2007) Invited review: amino acid bioavailability and digestibility in pig feed ingredients: Terminology and application. J Anim Sci 85, 172-180.

7. Batterham ES (1992) Availability and utilization of amino acids for growing pigs. Nutr Res Rev 5, 1-18.
8. Bos C, Mahé S, Gaudichon C, et al. (1999) Assessment of net postprandial protein utilization of $15 \mathrm{~N}$-labelled milk nitrogen in human subjects. BrJ Nutr 81, 221-226.

9. Mariotti F, Mahé S, Benamouzig R, et al. (1999) Nutritional value of $[15 \mathrm{~N}]-$-soy protein isolate assessed from ileal digestibility and postprandial protein utilization in humans. $J$ Nutr 129, 1992-1997.

10. Tomé D \& Bos C (2000) Dietary protein and nitrogen utilization. J Nutr 130, 1868S-1873S.

11. Darragh AJ \& Hodgkinson SM (2000) Quantifying the digestibility of dietary protein. J Nutr 130, 1850S-1856S.

12. Moughan PJ (2005) Dietary protein quality in humans-an overview. J AOAC Int 88, 874-876.

13. Moehn S, Bertolo RF, Pencharz PB, et al. (2005) Development of the indicator amino acid oxidation technique to determine the availability of amino acids from dietary protein in pigs. J Nutr 135, 2866-2870.

14. Humayun MA, Elango R, Moehn S, et al. (2007) Application of the indicator amino acid oxidation technique for the determination of metabolic availability of sulphur amino acids from casein versus soy protein isolate in adult men. J Nutr 137, 1874-1879.

15. Food and Agricultural Organization (1991) Protein quality evaluation in human diets. Report of a Joint FAO/WHO Expert Consultation. Rome, Food and Agriculture Organization of the United Nations. (FAO Food and Nutrition Paper No. 51). Geneva, Switzerland.

16. Schaafsma G (2005) The Protein Digestibility-Corrected Amino Acid Score (PDCAAS)-a concept for describing protein quality in foods and food ingredients: a critical review. J AOAC Int 88, 988-994.

17. Reeds P, Schaafsma G, Tomé D, et al. (2000) Criteria and significance of dietary protein sources in humans. Summary of the workshop with recommendations. J Nutr $\mathbf{1 3 0}$ 1874S-1876S.

18. Fuller MF \& Tomé D (2005) In vivo determination of amino acid bioavailability in humans and model animals. $J A O A C$ Int 88, 923-934.

19. Gilani GS, Cockell KA \& Sepehr E (2005) Effects of antinutritional factors on protein digestibility and amino acid availability in foods. J AOAC Int $\mathbf{8 8}, 967-987$.

20. Myrie SB, Bertolo RF, Sauer WC, et al. (2008) Effect of common antinutritive factors and fibrous feedstuffs in pig diets on amino acid digestibilities with special emphasis on threonine. J Anim Sci 86, 609-619.

21. Sarwar G (1997) The protein digestibility-corrected amino acid score method overestimates quality of proteins containing antinutritional factors and of poorly digestible proteins supplemented with limiting amino acids in rats. $J$ Nutr 127, 758-764.

22. Moughan PJ (2003) Amino acid availability: aspects of chemical analysis and bioassay methodology. Nutr Res Rev 16, $127-141$.

23. Knabe DA, LaRue DC, Gregg EJ, et al. (1989) Apparent digestibility of nitrogen and amino acids in protein feedstuffs by growing pigs. J Anim Sci 67, 441-458.

24. Moughan P, Gall MPJ \& Rutherfurd SM (1996) Absorption of lysine and deoxyketosyllysine in an early-maillard browned casein by the growing pig. I Agric Food Chem 14, $1520-1525$.

25. Rutherfurd SM \& Moughan PJ (1997) Application of a new method for determining digestible reactive lysine to variably heated protein sources. J Agric Food Chem 45, 1582-1586.

26. Moehn S, Bertolo RFP, Martinazzo-Dallagnol E, et al. (2007) Metabolic availability of lysine in feedstuffs determined using oral isotope delivery. Livest Sci 109, 24-26. 
27. Levesque CL, Moehn S, Pencharz PB, et al. (2011) The metabolic availability of threonine in common feedstuffs fed to adult sows is higher than published ileal digestibility estimates. J Nutr 141, 406-410.

28. Gausserès N, Mahé S, Benamouzig R, et al. (1997) [15N]labeled pea flour protein nitrogen exhibits good ileal digestibility and postprandial retention in humans. J Nutr 127, $1160-1165$.

29. Millward DJ, Fereday A, Gibson NR, et al. (2002) Efficiency of utilization of wheat and milk protein in healthy adults and apparent lysine requirements determined by a singlemeal [1-13C]leucine balance protocol. Am J Clin Nutr $\mathbf{7 6}$, $1326-1334$.

30. Millward DJ, Fereday A, Gibson NR, et al. (2000) Human adult amino acid requirements: [1-13C]leucine balance evaluation of the efficiency of utilization and apparent requirements for wheat protein and lysine compared with those for milk protein in healthy adults. Am J Clin Nutr 72, 112-121.

31. Juillet B, Saccomani MP, Bos C, et al. (2006) Conceptual, methodological and computational issues concerning the compartmental modeling of a complex biological system: Postprandial inter-organ metabolism of dietary nitrogen in humans. Math Biosci 204, 282-309.

32. Bos C, Juillet B, Fouillet H, et al. (2005) Postprandial metabolic utilization of wheat protein in humans. Am J Clin Nutr 81, 87-94.

33. Kurpad AV \& Young VR (2003) What is apparent is not always real: lessons from lysine requirement studies in adult humans. J Nutr 133, 1227-1230.

34. Pencharz PB \& Ball RO (2003) Different approaches to define individual amino acid requirements. Annu Rev Nutr 23, 101-116.

35. Elango R, Ball RO \& Pencharz PB (2008) Indicator amino acid oxidation: concept and application. J Nutr 138, $243-246$

36. Elango R, Ball RO \& Pencharz PB (2008) Individual amino acid requirements in humans: an update. Curr Opin Clin Nutr Metab Care 11, 34-39.

37. Ball RO, Moehn S \& Bertolo RF (2005) Next generation diet formulation: true metabolic availability of amino acids in diets for pigs. In Advances in Pork Production 16, 131-146.

38. Ball RO \& Bayley HS (1986) Influence of dietary protein concentration on the oxidation of phenylalanine by the young pig. BrJ Nutr 55, 651-658.

39. Rafii M, McKenzie JM, Roberts SA, et al. (2008) In vivo regulation of phenylalanine hydroxylation to tyrosine, studied using enrichment in apoB-100. Am J Physiol 294, E475-E479.

40. Elango R, Humayun MA, Ball RO, et al. (2009) Indicator amino acid oxidation is not affected by period of adaptation to a wide range of lysine intakes in healthy young men. J Nutr 103, 1082-1087.

41. Wykes LJ, Ball RO \& Pencharz PB (1993) Development and validation of a total parenteral nutrition model in the neonatal piglet. J Nutr 123, 1248-1259.
42. Ball RO, House JD, Wykes LJ, et al. (1996) A piglet model for neonatal amino acid metabolism during total parenteral nutrition. In Advances in Swine Biomedical Research, pp. 713-731 [ME Tumbleson and LB Schook, editors]. vol 2, New York, NY: Plenum Press.

43. Moughan PJ, Birtles MJ, Cranwell PD, et al. (1992) The piglet as a model animal for studying aspects of digestion and absorption in milk-fed human infants. World Rev Nutr Diet 67, 40-113.

44. Deglaire A, Bos C, Tomé D, et al. (2009) Ileal digestibility of dietary protein in the growing pig and adult human. $\mathrm{Br}$ J Nutr 102, 1752-1759.

45. Baker DH (1992) Applications of chemically defined diets to the solution of nutrition problems. Amino Acids 2, 1-12.

46. Chung TK \& Baker DH (1992) Apparent and true amino acid digestibility of a crystalline amino acid mixture and of casein: comparison of values obtained with ileal-cannulated pigs and cecectomized cockerels. J Anim Sci 70, 3781-3790.

47. Levesque CL, Moehn S, Pencharz PB, et al. (2010) Review of advances in metabolic bioavailability of amino acids. Livestock Sci 133, 4-9.

48. van Barneveld RJ, Batterham ES \& Norton BW (1994) The effect of heat on amino acids for pigs. 3. The availability of lysine from heat-treated field peas (Pisum sativum cultivar Dundale) determined using the slope-ratio assay. Br J Nutr 72, $257-275$.

49. Stein HH, Kim SW, Nielson TT, et al. (2001) Standardized ileal protein and amino acid digestibility by growing pigs and sows. J Anim Sci 79, 2113-2122.

50. LeGoff G \& Noblet J (2001) Comparative total tract digestibility of energy and nutrients in growing pigs and adult sows. J Anim Sci 79, 2418-2427.

51. King JC (2000) Physiology of pregnancy and nutrient metabolism. Am J Clin Nutr 71, 1218S-1225S.

52. Coffey KP, Paterson JA, Saul CS, et al. (1989) The influence of pregnancy and source of supplemental protein on intake, digestive kinetics and amino acid absorption by ewes. J Anim Sci 67, 1805-1814.

53. Burdett K \& Reek C (1976) Adaptation of the small intestine during pregnancy and lactation in the rat. Biochem $J \mathbf{1 8 4}$, 245-251.

54. Di Buono M, Wykes LJ, Ball RO, et al. (2001) Total sulfur amino acid requirement in young men as determined by indicator amino acid oxidation with L-[1-13C]phenylalanine. Am J Clin Nutr 74, 756-760.

55. Pederson C \& Boisen S (2002) Establishment of tabulated values for standardized ileal digestibility of crude protein and essential amino acids in common feedstuff for pigs. Acta Agric Scand Sect A Anim Sci 52, 121-140.

56. Fevrier C, Lechevestrier Y, Lebreton Y, et al. (2000) Prediction of the standardized ileal true digestibility of amino acids from the chemical composition of oilseed meals in the growing pig. Anim Feed Sci Technol 90, 103-115. 